\title{
НЕПЕРЕБОРНА СИЛА У ЗАКОНОДАВСТВІ ІТАЛІЇ, НІМЕЧЧИНИ ТА ФРАНЦІЇ: АСПЕКТИ РОЗУМІННЯ У ПУБЛІЧНОМУ ТА ПРИВАТНОМУ ПРАВІ
}

\section{Полонка I. А.}

\section{ВСТУП}

Свою юридичну значимість інститут невинуватого діяння набуває у разі констатації відсутності вини у діянні особи, яка порушує нормативноправові приписи і встановлений правопорядок. Але це лише одна грань цього складного явища. 3 більш широких позицій розуміння права, крім оцінки діяння, у співвідношенні винуватості/невинуватості відбивається міра розвитку громадського сприйняття та реагування на цю поведінку.

Тому встановлення меж винуватості/невинуватості у праві не тільки визначає ставлення права до поведінки індивіда, а й показує розвиток права у суспільстві. Теорія невинуватого діяння (що $€$ одним із різновидів об'єктивно-протиправного діяння) має перспективу виявити філігранні межі права, показати його міцний зв'язок з ідеями справедливості і свободи.

Зазначені обставини свідчать про необхідність активізації загальнотеоретичного пізнання сутності, змісту та специфіки такого правового феномена, a особливого практичного i наукового інтересу набуває проблема вироблення єдиної сучасної концепції про невинувате діяння у праві. При цьому видається важливим, щоб сформована теоретико-правова модель (концепція) найбільш повно і логічно несуперечливо відображала сутність аналізованого явища, його багатоаспектність і поліваріативність проявів у правовій дійсності.

Зважаючи на новітні тенденції глобалізації юриспруденції, для України необхідним видається дослідження досвіду саме європейських країн щодо врегулювання інституту невинуватого діяння. Інтеграція нашої держави у міжнародну спільноту вимагає реформування національного законодавства у всіх сферах права відповідно до загальновизнаних міжнародних стандартів.

Тому метою представленої роботи $є$ співвідношення реалізованих у романо-германській правовій сім’і підходів до розуміння категорії «непереборна сила» для визначення оптимальної правової моделі такого роду обставин у праві України.

Суттєвий внесок у вирішення проблеми щодо 3'ясування змісту інституту «непереборна сила» зробили у своїх працях, зокрема, такі вчені, 
як: О. Ашурков, С. Бакунін, О. Білоус, О. Братель, В. Бурдін, А. Буркова, I. Бурлака, I. Канзафарова, Е. Кондратьєва, Ю. Клюєва, О. Мельник, А. Мискін, О. Осіпова, В. Примак, М. Сироєжкіна, С. Теньков, Н. Терещенко, О. Церковна та інші.

Однак питання розуміння досліджуваної категорії у публічному та приватному праві в Україні та за ії межами у наукових працях вивчалося лише фрагментарно, тому пропонуємо більш грунтовно та комплексно дослідити іiі.

Інститут невинуватого діяння як складне правове явище повинне вивчатися комплексно, зважаючи на всі істотні характеристики його різновидів, а саме діяння під впливом непереборної сили («форс-мажор») та «казусне» (випадкове) здійснення суспільно шкідливого діяння.

Крім цього, таке явище слід розглядати у динаміці, тобто взаємозв'язку iз загальним баченням права як системи взаємозумовленості публічноправової і приватноправової сфер та 3 уявленнями про прояв поведінки особи у механізмі правового регулювання.

Зупинимося детальніше на розумінні діяння вчиненого під впливом непереборної сили («форс-мажор») на прикладі законодавства та правової доктрини країн романо-германської правової сім’ї у приватноправовій та публічно-правовій сферах.

\section{1. Розуміння діяння, вчиненого під впливом непереборної сили («форс-мажору»), на прикладі законодавства та правової доктрини Італії та Франції у приватноправовій та публічно-правовій сферах}

\section{1. Італія}

1.1.1. Публічне (кримінальне) право. Серед таких обставин, у разі яких діяння формально містить ознаки злочину, описаного у законі, однак не $\epsilon$ злочинним і караним у кримінальному праві Італії, виділяють: дію непередбаченого випадку та непереборної сили.

Відповідно до ст. 45 Кримінального кодексу Італії від кримінальної відповідальності звільняється особа, яка вчинила діяння через непередбачений випадок або непереборну силу, оскільки в їі діях не було провини ${ }^{1}$. Під непереборною силою, яка є обставиною, що звільняє від кримінальної відповідальності, розуміються події природного характеру або дії людей, яких неможливо уникнути, навіть якщо б вони і були передбачені.

Неординарною є норма Кримінального кодексу Італії, яка виключає або зменшує покарання для осіб, які через непередбачений випадок чи

\footnotetext{
${ }^{1}$ Уголовный кодекс Италии / науч. ред. А.И. Коробеева. Санкт-Петербург : Юридический центр Пресс, 2003. Ст. 45.
} 
непереборну силу перебували у стані сп'яніння. Але особа прирівнюється до осудної, якщо вона власноруч призвела себе у стан «нездатності усвідомлювати i бажати» 3 метою вчинення правопорушення або приготувати собі виправдання. У цих випадках, а також якщо неправомірне діяння вчинене у стані звичайного сп'яніння, стан сп'яніння підвищує покарання (ст. 87, ст. 92-94).

1.1.2. Приватне (цивільне) право. Не менш актуальним є дослідження такої проблеми у приватноправовій сфері, позаяк досить часто у ній спостерігається наявність юридичної відповідальності «без вини», що свідчить про відсутність «єдиного пояснювального фундаменту» цієї дилеми у сучасній юриспруденції.

Італійське право надає стороні у договірному зобов'язанні можливість розірвати договір у тому разі, якщо його виконання стає надмірно обтяжливим (скрутним) внаслідок непередбачених обставин.

\section{2. Франція}

1.2.1. Публічне (кримінальне) право. Згідно зі ст. 122-2 Кримінального кодексу Франції не підлягає кримінальній відповідальності особа, яка діяла під впливом тієї чи іншої сили або примусу, яким вона не могла протистояти ${ }^{2}$. Кримінальне законодавство держав - колишніх французьких колоній (Алжир, Мадагаскар, Марокко, Сенегал) і деяких інших держав, які зазнали французького впливу (Бельгія, Мальта, Нідерланди, Еквадор), також виключають кримінальну відповідальність у разі примусу силою, якій неможливо було протистояти.

Судова практика, своєю чергою, інтерпретуючи зміст поняття «примус», який виключає злочинний характер діяння, має на увазі і фізичний примус, і природні (стихійні) сили, які є непереборними.

Що стосується психічного примусу, то позиція французького законодавця не є настільки категоричною. Здійснення незаконних дій унаслідок такого примусу може братися до уваги під час призначення покарання як обставина, що його пом'якшує.

Спостерігається такий причинно-наслідковий зв'язок: фізичний примус викликається подією або дією, яка не залежала від бажання того, кого примушують, і полягає в абсолютному виключенні волі особи.

Категорії «примушення», «форс-мажорні обставини» i «непереборна сила» у кримінальному праві Франції трактуються як тотожні.

1.2.2. Приватне (цивільне) право. Французьке цивільне право розмежування між випадком і непереборною силою також не проводить, i обидва поняття вживаються у ньому як синоніми.

\footnotetext{
${ }^{2}$ Уголовный кодекс Франции / науч. ред. Л.В. Головко, Н.Е. Крылова; пер. с фр. Н.Е. Крыловой. Санкт-Петербург : Юридический центр Пресс, 2002. Ст. 122-2.
} 
Натомість приватне право Франції висуває певні критерії, яким мають відповідати випадок або непереборна сила: обставина має бути сторонньою для боржника, тому не пов'язаною $з$ його особистістю і виникати поза його волею; обставина має бути непередбаченою, причому 3 точки зору абстрактних критеріїв, а не виходячи з можливостей такого боржника; події повинні бути невідворотними і неминучими, тобто не досить, щоб вони створювали лише труднощі для боржника (навіть якщо вони дуже серйозні, мають надзвичайний характер і значно обтяжують його положення).

Тому французьке законодавство і практика не визнають самі по собі, до прикладу, війну або страйк непереборною силою. Лише деякі факти, які $\epsilon$ наслідком війни, такі як реквізиція, нальоти, руйнування, можуть бути кваліфіковані як обставини, що звільняють від відповідальності.

Законодавча регламентація інституту непереборної сили у цивільному праві Франції останніми роками істотно змінилася. До 2016 р. досліджуване явище регулювалося ст. 1148 Цивільного кодексу Франції, у якій йшлося про те, що підстави для стягнення збитків відсутні, коли перепони, що виникли внаслідок дії непереборної сили чи випадку, не дали змогу боржникові надати чи зробити те, що він зобов'язаний був зробити, чи коли він зробив те, що йому було заборонено ${ }^{3}$.

3 вищесказаного випливає, що легального визначення терміна «непереборна сила» у французькому праві до 2016 року не було. Окремі положення Цивільного кодексу Франції обмежувалися або згадуванням таких обставин як обставин, що звільняють від відповідальності, або перерахуванням конкретних обставин (наприклад, ст. 1773 ФЦК).

Ідея про закріплення дефініції категорії «непереборна сила» безпосередньо у законодавчих положеннях під час розробки Цивільного кодексу Франції була відхилена через загальновідомість того, що під форсмажорними обставинами розуміються ті нещасні випадки, які з людського досвіду не можна було передбачити і запобігти.

Однак у лютому 2016 року відбулося реформування окремих норм цивільного права Франції. Ця реформа торкнулася i інституту непереборної сили. Отже, до Цивільного кодексу Франції було включено нову редакцію ст. 1218, яка гласить: «У договірних питаннях виникає форс-мажор, коли подія, що не перебуває під контролем боржника, яку не можна було розумно передбачити на момент укладення договору i наслідки якої не вдалося уникнути відповідними заходами, перешкоджає виконанню боржником свого зобов'язання» ${ }^{4}$.

\footnotetext{
${ }^{3}$ Французский гражданский кодекс / науч. ред. Д.Г. Лавров. Санкт-Петербург : Юридический центр Пресс, 2004. 368 с. Ст. 1148.

4 Будылин С. Реформа французского ГК: Сводка ключевых новелл. URL: https://zakon.ru/blog/ 2016/3/17/reforma_francuzskogo_gk_svodk_klyuchevyh_novell (дата звернення: 02.03.2018).
} 
Якщо запобігання тимчасове, виконання зобов'язання призупиняється, якщо затримка у результаті не виправдовує розірвання договору. Якщо запобігання є постійним, договір припиняється дією закону, і сторони звільняються від своїх зобов'язань на умовах, передбачених статтями 1351 та 1351-1 Цивільного кодексу Франції. Відповідно до наведених вище статей неможливість виконання зобов'язання звільняє боржника тією мірою, коли це неможливо та якщо це $\epsilon$ наслідком події форс-мажорних обставин і є остаточним, якщо він не погодився нести ризик події або раніше не був повідомлений про це.

Однак, якщо неможливість виконання є результатом втрати заборгованої речі, боржник, якому було повідомлено про виконання, все-таки звільняється, якщо він доведе, що збиток однаковою мірою відбувся б, якби його зобов'язання було виконане.

Нова інтерпретація законодавчого врегулювання категорії непереборна сила у Цивільному кодексі Франції вказує, що форс-мажор встановлюється лише в тому разі, якщо сталася подія, яка:

а) перебуває поза контролем сторін;

б) непередбачувана у час укладення угоди, поза якою виникають обов'язки сторін;

в) робить виконання зобов'язання сторони, що не виконує, абсолютно неможливою.

Тобто відповідно до чинної редакції ст. 1218 Цивільного кодексу Франції до ознак форс-мажору можна віднести: непередбачуваність, неминучість, неконтрольованість i ефект неможливості зробити зобов'язання сторони неможливим. Наведені вимоги, на думку сучасних іноземних науковців, повністю відповідають міжнародній арбітражній практиці $i^{5}$.

Хоча слід відзначити, що у французькій цивілістиці дотепер немає єдиної думки про окремі ознаки force majeure. Доктрина і судова практика Франції виробили такі критерії обставин, які звільняють боржника від відповідальності, без різниці - випадку або непереборної сили:

а) непередбаченість, тобто неможливість передбачення визначається, виходячи не зі спроможностей конкретної особи, а 3 абстрактних критеріїв. Більш того, явище має мати цю властивість стосовно всіх супроводжуючих його обставин (час, місце виникнення), а також бути непередбаченим на момент укладення договору;

\footnotetext{
${ }^{5}$ Berger Klaus Peter. Force Majeure Clauses and their Relationship with the Applicable Law, Trade Usages and General Principles of Law, in: Bortolotti/Ufot (Hrsg.), Hardship and Force Majeure in International Commercial Contracts, Dealing with unforeseen events in a changing world, ICC Institute of World Business Law, Dossier XVIII, 2018, p. 133.
} 
Іноді французькі суди вимагають, щоб ця обставина була несподіваною не тільки для звичайної людини, але і для особи, що позивається на неї. Знання боржником особливих обставин, що супроводжували настання неможливості виконання, дає судам підставу не визнавати обставини форсмажорними.

Деякі зарубіжні цивілісти бачать у цьому критерії причину того, що ознака непередбачуваності ставиться під сумнів у французькій юридичній літературі та іноді взагалі не використовується у разі кваліфікації непереборної сили, оскільки за такого розуміння практично кожна перешкода виконання договору є передбачувана

б) неминучість, під якою розуміється неможливість перешкоджати настанню обставин відповідною розумною поведінкою. А для того щоб подія могла розглядатися як неминуча, не досить, щоб вона створила лише труднощі для боржника. Така подія має бути невідворотною і зробити дотримання договірних умов неможливими.

Слід зазначити, що у французькій доктрині $є$ спірним питання, чи повинні неминучість і непередбачуваність бути присутніми одночасно для кваліфікації обставини умовами, що звільняють від відповідальності або досить наявності однієї із цих ознак.

Подекуди і судова практика, і вчені-юристи Франції часом взагалі відмовляються від застосування критеріїв неминучості i непередбачуваності. Натомість використовується критерій певною мірою дбайливості боржника, причому масштаб необхідного ступеня дбайливості сильно завищують. Для звільнення від відповідальності боржник зобов'язаний вжити всіх можливих заходів для запобігання нещасного випадку. I ставиться питання не про те, чи міг боржник передбачити або запобігти таким обставинам, а про те, чи повинен був він їм запобігти.

в) наступним критерієм обставин непереборної сили, що звільняє боржника від відповідальності, є ознака, яка не пов'язана з особистістю боржника, тому що не викликана ним і виникає поза його волею. У цьому контексті йдеться про вплив певної сторонньої причини, яка унеможливлює виконання зобов'язань та є не контрольованою.

Підсумовуючи, хочеться виділити факт детального опрацювання французьким законодавцем протягом останніх років проблеми інституту непереборної сили та вказати на закріплення цієї категорії на нормативному рівні.

Однак недоліком врегулювання інституту непереборної сили у Франції є ототожнення термінів «непереборна сила» і «випадок» (казус). Хоча такі явища і $\epsilon$ досить схожими, однак вони різняться між собою: у разі

\footnotetext{
${ }^{6}$ Fontane G. Ho-here Gewalt im Dokumenten akkreditivges-chaft. Frankfurt am Main : Lang, 2001. S. 67.
} 
непереборної сили негативні наслідки настають незалежно від їх передбачуваності і вжиття можливих у такій ситуації заходів.

\section{2. Розуміння діяння, вчиненого під впливом непереборної сили} («форс-мажору»), на прикладі законодавства та правової доктрини Німеччини у приватноправовій та публічно-правовій сферах

\section{1. Публічне (кримінальне) право}

У німецькому кримінальному праві на законодавчому рівні категорія «непереборна сила» не вживається. Однак діє принцип «зважування інтересів», а також об'єктивні і суб'єктивні виправдувальні ознаки діяння. Наукова доктрина Німеччини трактує результат як передбачуваний предметний вимір, а не мету, якої хоче досягти особа. Намір включає у себе знання і волю, які мають різну інтенсивність, що не прив'язується в обов'язковому порядку до наслідків і оцінюється відповідно до обставин, що усувають протиправність діяння.

Також § 15 Кримінального кодексу ФРН вказує, що караним є лише умисне діяння, якщо законом буквально не загрожує покарання за необережне діяння ${ }^{7}$.

Форс-мажор у німецькій юриспруденції розуміється як неминуча подія, така як природні катастрофи будь-якого виду, особливо землетруси, урагани, виверження вулканів, посухи, смерчі, зсуви та інші. Вказане явище вимагає абсолютно несподіваного настання однієї із цих подій. Однак якщо настання події можна очікувати, як, наприклад, у разі повеней, які повторюються знову і знову в одних і тих же регіонах, то форс-мажору не буде.

У разі дорожньо-транспортної пригоди форс-мажор передбачає, що шкідливий випадок, мабуть, мав зовнішній вплив на роботу транспортного засобу і повинен бути настільки винятковим, що власнику чи водієві зовсім не потрібно було про це турбуватися. Згідно 3 прецедентною практикою Федерального Суду Німеччини щодо інших випадків застосування правила відповідальності за форс-мажор, ця подія повинна бути спричинена стихійними силами природи або діями третіх осіб.

Аналогічним чином вирішено питання щодо віднесення стихійних лих до категорії непереборних обставин i в англо-американському та французькому праві. Однак спірним залишається момент, що стосується суспільних подій.

Однак французький та англійський терміни не тотожні німецькому форс-мажору. Законодавство Франції форс-мажорні обставини розуміє як

\footnotetext{
${ }^{7}$ Головненков П.В. Уголовное уложение Федеративной Республики Германия : научно-практический комментарий и перевод текста закона. 2-е изд. Москва : Проспект, 2016. Ст. 15.
} 
непереборну силу у вузькому сенсі природних явищ; стосовно подій, спричинених людиною, французька юридична традиція використовує технічний термін (франц. cas fortuit).

У країнах англо-американського права у юридичній мові часто вживається вираз “act of God" (дія Бога), який англійськими правниками пояснюється не як дія Бога у біблійному значенні, а маються на увазі надзвичайні обставини, які не можна було передбачити або запобігти.

Можна підсумувати, що кримінальне право Німеччини категорію «непереборна сила» на законодавчому рівні не вживає. А у разі виникнення проблем, що стосуються винуватості особи, приймається до уваги таке: якщо не доведена свобода прояву волі, враховуються факти на користь особи, які діють у суспільстві і виключають вину.

\section{2. Приватне (цивільне) право}

Цивільний кодекс Німеччини на противагу Цивільному кодексу Франції намагається відмежувати випадок від непереборної сили, позначаючи непереборну силу як «кваліфікований випадок».

На наш погляд, тлумачення непереборної сили шляхом використання поняття «випадок», навіть як кваліфікований, є неприйнятним. Випадок характеризує суб'єктивне відношення боржника до невиконання чи неналежного виконання умов договору.

Непереборна сила - це інше поняття, яке не має нічого спільного із суб'єктивним відношенням боржника до виконання договору. Це зовнішня обставина, яка характеризується для боржника невідворотністю та надзвичайністю. $\mathrm{У}$ разі одночасної присутності двох указаних характеристик така обставина трансформується у непереборну силу. Тобто у такий вплив ззовні, якому за цих умов контрагент не може протидіяти. Йому залишається лише сподіватися на можливість успішного результату $\mathrm{i}$ спробувати мінімізувати несприятливі наслідки.

Що стосується первісної неможливості виконання зобов'язання, французька та німецька доктрина сприйняли один з основних принципів романо-германської системи права, відомий ще римському праву: зобов'язання, що має своїм змістом те, що неможливо виконати, $\epsilon$ юридично нікчемним (imossibilium nulla est obligatio). Так, відповідно до параграфу 275 Цивільного кодексу Німеччини неможливе не може ставитися в обов'язок боржнику.

Багато у чому схоже 3 французьким 3 точки зору принципів підходу до проблеми непереборної сили німецьке право. Але, на відміну від

\footnotetext{
${ }^{8}$ Гражданское уложение Германии : Вводный закон к Гражданскому уложению / пер. с нем. В. Бергманн, введ., сост. науч. ред. Т.Ф. Яковлева. 4-е изд., перераб. (Серия «Германские и европейские законы»; Книга 1), Москва, 2015, п. 275.
} 
французького права, воно не містить законодавчого регулювання впливу непереборної сили (höhere Gewalt) на договірне зобов'язання і на договірну відповідальність боржника. Проте навіть за відсутності такого регулювання настання обставин непереборної сили тягне за собою припинення обов'язку відповідати за завдані збитки.

Як зазначається в юридичній літературі, не можна говорити про наявність інституту непереборної сили у німецькому праві ${ }^{9}$.

Під час обговорення проєкту Цивільного кодексу Німеччини дискутувалося питання про використання у тексті закону терміна «непереборна сила». Висновок правової комісії говорить: «використання поняття «непереборна сила» у цивільному праві недоречне, більше того, всюди, де у законі воно передбачається або мається на увазі, потрібне закріплення його сенсу у позитивному ставленні» ${ }^{10}$.

Незважаючи на всі застереження, категорія «непереборна сила» все ж таки включена у Цивільний кодекс Німеччини і в інші закони. Але іiі легальне визначення у німецькому праві відсутнє. Пояснюється це тим, що під час складання проєкту вказаного кодексу виходили 3 популярності цього поняття.

У німецькій юриспруденції наявні відмінні один від одного підходи до сутності та значення непереборної сили. Якщо одні автори характеризують обставини непереборної сили як загадку і як явище, надзвичайно неясне i тому не має сенсу в юридичній науці, яке слід виключити із законодавчих положень, то інші, навпаки, незважаючи на те, що це поняття припускає неоднозначне його тлумачення, висловлюються за його збереження, позаяк воно служить роз'ясненню низки важливих проблем, що залишилися прихованими від очей законодавця ${ }^{11}$.

У результаті довгих дискусій про сутність непереборної сили німецька цивілістика зупинилася на об'єктивно-суб'єктивному підході Л. Еннекцеруса. Цікаво зазначити, що у новітній судовій практиці поняття «непереборна сила» визначається набагато суворіше, ніж у практиці Імперського суду Німеччини. Так, Вищим судом Німеччини дається таке визначення: «Непереборна сила - це обставина, що є сторонньою стосовно діяльності боржника, породжена елементарними силами природи або діями третіх осіб, непередбачена при всьому людському досвіді i розсудливості, яка не може бути попередженою у разі крайнього ступеня дбайливості i застосування економічно допустимих засобів, обліку

\footnotetext{
${ }^{9}$ Stidtler U. Schadensersatz im Falle ho-herer Gewalt? Gettingen, 1986. S. 13.

${ }^{10}$ Stobbe U. Hehere Gewalt: eine rechtshistorische Untersuchung. Gettingen, 1963. S.70.

${ }^{11}$ Brunner K. Die Haftung nach Bürgerlichem Recht und die höhere Gewalt. Bonn, 1904. S. 3.
} 
настання якого неможливо вимагати від боржника відповідно до частоти настання цієї обставини» ${ }^{12}$.

Говорячи про термін «непереборна сила» у німецькому праві, слід виділити його основні ознаки, які мають бути присутніми одночасно:

а) непередбаченість за всього людського досвіду і розсудливості. На відміну від французького, у німецькому праві для визнання ознаки непередбачуваності використовується суб'єктивний масштаб оцінки. Абстрактна передбачуваність не має значення, позаяк абстрактно практично кожна перешкода виконання договору $є$ передбачуваною.

Водночас у судовій практиці спостерігається відступ від критерію непередбачуваності як характеристики обставин непереборної сили. У доктрині німецького цивільного права останнім часом успішно аргументується думка про те, що непередбаченість не є характеристикою непереборної сили ${ }^{13}$.

б) невідворотність, тобто боржник має право посилатися на обставину непереборної сили, тільки якщо він у разі використання всіх економічно можливих засобів, наявних у його розпорядженні, не зміг запобігти такій обставині. При цьому необхідно дотримуватися крайньої міри дбайливості, яка значно відрізняється від необхідної.

У процесі доведення ознаки невідворотності боржник зобов'язаний у деталях зазначити, які заходи запобігання могли бути ним прийняті, чи були вони прийняті, а також чи було їх прийняття неможливим і якщо так, то з якої причини виникла ця неможливість.

в) зовнішній характер стосовно діяльності боржника. Значення має не місце виникнення обставин, а внутрішній зв'язок між небезпекою, що виходить від діяльності боржника, і реалізованим ризиком.

Можна підкреслити, що німецька судова практика висуває дуже високі вимоги до ознаки зовнішнього характеру обставин. Часто ця ознака не знаходить підтвердження у суді. Так, у справі про відшкодування збитків, завданих туристам у результаті пожежі на кораблі, суд відмовив у визнанні цієї обставини непереборною силою $з$ посиланням на те, що пожежа виникла на кораблі у районі кают екіпажу судна, машинного відділення і кухні, що свідчить про відсутність зовнішнього характеру впливу.

г) надзвичайність (обставини, які не можуть бути прийняті до уваги боржником через незвичайність і рідкість явищ такого ступеня). Наприклад, непереборною силою був визнаний найсильніший грозовий дощ, який трапляється раз у 20 років.

\footnotetext{
${ }^{12}$ URL: https://www.bundesgerichtshof.de/DE/Home/home_node.html.

${ }^{13}$ Brennecke C. Hohere Gewalt im Reisevertragsrecht. Koln, 2003. S. 67.
} 
Надзвичайна обставина характеризується не тільки тим, що вона настає рідко, але і тим, що вона $є$ «небаченою і нечуваною», значною мірою перевершує звичайні обставини. До прикладу, національний траур був оцінений судом як непереборна сила, коли за укладеним договором замовник відмовився від послуг музичного супроводу у вигляді «веселої танцювальної музики».

Надзвичайна обставина характеризується і тим, що вона не належить до звичайного життєвого ризику. Тобто межа непереборної сили проходить там, де явище оцінюється як «нормальне» для боржника. Саме таке розуміння видається нам корисним у вітчизняній цивілістиці. При цьому оцінка надзвичайності обставини залежить від місця і часу того, що відбувається ${ }^{14}$.

Ознака надзвичайності відіграє важливу роль у концепції непереборної сили у праві Німеччини, позаяк без цієї властивості неможливо було б розрізнити обставини непереборної сили та випадку.

\section{ВИСНОВКИ}

1. Провівши дослідження кримінального законодавства деяких європейських країн, можна 3 упевненістю говорити про наявність трьох підходів: 1) на законодавчому рівні передбачено поняття «непереборна сила» (Італія); 2) непереборна сила визначається у межах інших кримінально-правових понять (Франція); 3) нормативне визначення непереборної сили відсутнє (Німеччина).

2. Наведено у представленій роботі порівняння розуміння категорії «непереборна сила» у кримінальному законодавстві країн Франції, Німеччини та Італії, яке явно відрізняється від законодавства України. До прикладу, відповідно до норм Кримінального кодексу Франції джерелом виникнення стану примусу є не лише дії людини, а й будь-які зовнішні сили, які позбавляють особу свободи волі і примушують їі порушувати закон. Натомість у вітчизняному праві остання обставина отримала назву як «непереборні сили природи», яка належить відповідно до норм Кримінального кодексу України до іншої обставини, яка виключає злочинність діяння - крайньої необхідності.

Кримінальне право Франції досить виправдано вказує на розбіжності між крайньою необхідністю та фізичним примусом. Аргументованим видається твердження, що у разі крайньої необхідності особа завдає шкоди активно, маючи на меті відвернути або усунути небезпеку, що їй загрожує. А у разі фізичного примусу шкода особою завдається пасивно, через неможливість протистояти певним зовнішнім обставинам.

\footnotetext{
${ }^{14}$ Filthaut W. Kommentar zum Haftpflichtgesetz. Band 39. 7. Auflage. München, 2006. § 1, Rn. 163. S. 99.
} 
3. Сутність непереборної сили у приватному праві романо-германської правової сім'ї залишається спірною. Доктрина і судова практика Італії, Франції та Німеччини загалом однаково підходять до визначення змісту непереборної сили, але $є$ і особливості, що виражаються у різній оцінці окремих їі критеріїв. У французькому праві зовнішній характер обставини у сенсі німецького права не має вирішального значення, а надзвичайність за правом Франції взагалі не виділяється як кваліфікуюча ознака. На відміну від німецького, французьке право ознаку неминучості обставини трактує більш суворо: виходячи з об’єктивного критерію. Крім того, непередбаченість оцінюється у Франції за абстрактним, а в Німеччині - за конкретним критерієм.

У договірному праві Німеччини поняття «непереборна сила» використовується тільки в окремих випадках, а за французьким правом у разі невиконання чи неналежного виконання договору постійно спочатку з'ясовується питання про те, чи не перешкоджала виконанню обставина непереборної сили. У німецькому праві виникає питання тільки про неможливість виконання договірного зобов'язання. Позаяк поняття "hehere Gewalt” сформоване у німецькому праві спочатку в сфері деліктного права і тільки пізніше було поширене на договірне право. Тоді як французьке "force majeure" з'явилося вперше для усунення наслідків порушення договору.

У результаті досліджуваних ознак непереборної сили вітчизняній цивілістиці доцільно взяти до уваги ознаки, які використовуються у німецькому праві, а саме: надзвичайність, непередбачуваність, невідворотність і зовнішній характер обставини. Їх комплексний та цілісний характер допоможуть захистити права і боржника, і кредитора.

4. Для можливого запозичення позитивного світового досвіду щодо врегулювання інституту невинуватого діяння в Україні слід прийняти до уваги норми Кримінального кодексу Італії, де, на відміну від інших країн, присутнє належне його законодавче визначення. Не викликає сумніву досить проблематичний та суперечливий характер досліджуваного явища, що аргументовано підтверджує нагальність виділення різновидів цього складного феномена в окремій статті Кримінального кодексу України серед обставин, що звільняють від кримінальної відповідальності.

Вкажемо, що у теорії вітчизняного кримінального права, крім обставин, що виключають злочинність діяння, передбачених Кримінальним кодексом України, все ж таки виділяють і непереборну силу. Кримінальна відповідальність не настає за дії непереборної сили, під якою розуміється дія стихійних сил природи (землетруси, повені, пожежі тощо), людей (страйки, демонстрації, блокади, громадські безпорядки, воєнні дії тощо), 
звірів, інших надзвичайних або невідворотних факторів (наприклад, техногенна катастрофа, фізіологічні процеси), через які особа позбавлена реальної можливості виконати покладений на неї правовий обов'язок.

Із наведеного випливає, що непереборна сила, спеціальна регламентація якої у чинному Кримінальному кодексі відсутня, повинна повною мірою заважати особі вчинити діяння, яке відображає її волю.

У Цивільному кодексі України термін «форс-мажор» не використовується, проте у п. 1 ч. 1 ст. 263 визначено поняття «непереборна сила» як надзвичайної або невідворотної за таких умов події ${ }^{15}$. Тобто законодавець України виділяє тільки дві ознаки непереборної сили надзвичайність або невідворотність. А відповідно до норм ст. 617 ЦК України непереборна сила визнається підставою для звільнення від відповідальності за порушення зобов'язання, якщо особа доведе, що порушила його саме внаслідок непереборної сили.

Вищенаведене ще раз підтверджує той факт, що в Україні правове регулювання цивільних відносин, обтяжених впливом непереборної сили, на законодавчому рівні не містить обгрунтованого та повного її визначення та критеріїв як обставини, що звільняє від відповідальності.

\section{АНОТАЦІЯ}

У статті проаналізовано законодавство зарубіжних країн, судова практика та наукова доктрина щодо розуміння інституту невинуватого діяння, а саме одного із його різновидів - діяння, вчиненого під впливом непереборної сили («форс-мажор»).

Встановлення меж винуватості/невинуватості у праві визначає ставлення права до поведінки індивіда, а також показує розвиток права у суспільстві. Теорія невинуватого діяння (що $є$ одним із різновидів об'єктивнопротиправного діяння) має перспективу виявити філігранні межі права, показати його міцний зв'язок з ідеями справедливості і свободи.

Вивчено інститут непереборної сили у динаміці, тобто взаємозв'язку із загальним баченням права як системи взаємозумовленості публічноправової і приватноправової сфер та з уявленнями про прояв поведінки особи у механізмі правового регулювання.

У процесі дослідження кримінального законодавства деяких європейських країн виведено три підходи, які вказують на рівень нормативного закріплення явища непереборної сили: 1) на законодавчому рівні передбачено поняття непереборної сили; 2) непереборна сила

\footnotetext{
${ }^{15}$ Цивільний кодекс України від 16.01.2003 № 435-IV Відомості Верховної Ради Украӥни. 18.12.2016. URL: http://zakon2.rada.gov.ua/laws/show/435-15/conv/page.
} 
визначається у межах інших кримінально-правових понять; 3) нормативне визначення непереборної сили відсутнє.

У статті здійснено порівняння розуміння категорії «непереборна сила» у кримінальному законодавстві країн Франції, Німеччини та Італії, встановлено, що норми вказаних країн явно відрізняються від законодавства України.

Для можливого запозичення позитивного світового досвіду щодо врегулювання інституту невинуватого діяння в Україні слід прийняти до уваги норми Кримінального кодексу Італії, де, на відміну від інших країн, присутнє належне його законодавче визначення.

У процесі дослідження встановлено, що сутність непереборної сили у приватному праві романо-германської правової сім'ї залишається спірною. У результаті розглядуваних ознак непереборної сили вітчизняній цивілістиці доцільно взяти до уваги ознаки, які використовуються у німецькому праві, а саме: надзвичайність, непередбачуваність, невідворотність і зовнішній характер обставини.

\section{ЛIТЕРАТУРА}

1. Уголовный кодекс Италии / науч. ред. А.И. Коробеева. СанктПетербург : Юридический центр Пресс, 2003. 321 с.

2. Уголовный кодекс Франции / Науч. ред. Л.В. Головко, Н.Е. Крылова; пер. с фр. Н.Е. Крыловой. Санкт-Петербург : Юридический центр Пресс, 2002. $650 \mathrm{c}$.

3. Французский гражданский кодекс / науч. ред. Д.Г. Лавров. СанктПетербург : Юридический центр Пресс, 2004. 368 с.

4. Будылин С. Реформа французского ГК: Сводка ключевых новелл. URL: https://zakon.ru/blog/2016/3/17/reforma_francuzskogo_gk_svodk_klyuch evyh_novell (дата звернення: 02.03.2018).

5. Berger Klaus Peter. Force Majeure Clauses and their Relationship with the Applicable Law, Trade Usages and General Principles of Law, in: Bortolotti/Ufot (Hrsg.), Hardship and Force Majeure in International Commercial Contracts, Dealing with unforeseen events in a changing world, ICC Institute of World Business Law, Dossier XVIII, 2018, p. 133.

6. Fontane G. Ho-here Gewalt im Dokumenten akkreditivges-chaft. Frankfurt am Main : Lang, 2001. S. 67.

7. Головненков П.В. Уголовное уложение Федеративной Республики Германия: научно-практический комментарий и перевод текста закона. 2-е изд. Москва : Проспект, 2016. 312 с

8. Гражданское уложение Германии : Вводный закон к Гражданскому уложению / пер. с нем. В. Бергманн, введ., сост. науч. ред. Т.Ф. Яковлева. 
4-е изд., перераб. (Серия «Германские и европейские законы»; Книга 1), Москва, 2015, 888 c.

9. Stidtler U. Schadensersatz im Falle ho-herer Gewalt? Gettingen, 1986. S. 13. 10. Stobbe U. Hehere Gewalt: eine rechtshistorische Untersuchung. Gettingen, 1963. S.70.

11. Brunner K. Die Haftung nach Bürgerlichem Recht und die höhere Gewalt. Bonn, 1904. S. 3.

12. URL: https://www.bundesgerichtshof.de/DE/Home/home_node.html.

13. Brennecke C. Hohere Gewalt im Reisevertragsrecht. Koln, 2003. S. 67.

14. Filthaut W. Kommentar zum Haftpflichtgesetz. Band 39. 7. Auflage. München, 2006. § 1, Rn. 163. S. 99.

15. Цивільний кодекс України від 16.01.2003 № 435-IV Вiдомості Верховної Ради України. 18.12.2016 URL: http://zakon2.rada.gov.ua/laws/ show/435-15/conv/page.

16. Гражданский кодекс Италии. URL: http://www.jus.unitn.it/cardozo/ Obiter_Dictum/codciv/home.html.

\section{Information about author: \\ Polonka I. A., \\ Doctor of Law,}

Associate Professor at the Department of Professional and Specialized Legal Disciplines Private Higher Educational Institution "Bukovinian University" 2A, Darwin str., Chernivtsi, 58000, Ukraine 